\title{
A Perfect Storm in Interventional Pain Management: Regulated, but Unbalanced
}

Ramsin M. Benyamin, MD¹, Sukdeb Datta, MD², and Frank J.E. Falco, MD³

\section{From: ${ }^{\text {Millennium Pain Center }}$ Bloomington, IL; ${ }^{2}$ Vanderbilt University Medical Center, Nashville \\ TN; ${ }^{3}$ Mid Atlantic Spine \& Pain Specialists of Newark, Newark, DE. Dr. Benyamin is the Medical Director, Millennium Pain Center, Bloomington, \\ IL, Clinical Assistant Professor \\ of Surgery, College of Medicine, University of Illinois, Urbana- Champaign, IL. \\ Dr. Datta is Director, Vanderbilt University Interventional Pain Program, and Associate Professor, Dept. of Anesthesiology, Vanderbilt University Medical Center, Nashville TN. \\ Dr. Falco is Medical Director of the Mid Atlantic Spine \& Pain Specialists of Newark, DE, and Clinical Assistant Professor, Temple University Medical School, Philadelphia, PA. \\ Address correspondence: Ramsin M. Benyamin, MD Millennium Pain Center 1015 S. Mercer Bloomington, IL 61701 E-mail: \\ ramsinbenyamin@yahoo.com}

Disclaimer: There was no external funding in the preparation of this manuscript. Conflict of interest: None.

Manuscript received: 03/02/2010 Accepted for publication: 03/10/2010

Free full manuscript: www.painphysicianjournal.com
Interventional pain management now stands at the crossroads at what is described as "the perfect storm." The confluence of several factors has led to devastating results for interventional pain management. This article seeks to provide a perspective to various issues producing conditions conducive to creating a "perfect storm" such as use and abuse of interventional pain management techniques, and in the same context, use and abuse of various non-interventional techniques. The rapid increase in opioid drug prescribing, costs to health care, large increases in death rates, and random and rampant drug testing, can also lead to increases in health care utilization. Other important aspects that are seldom discussed include medico-legal and ethical perspectives of individual and professional societal opinions and the interpretation of diagnostic accuracy of controlled diagnostic blocks.

The aim of this article is to discuss the impact of several factors on interventional pain management and overuse, abuse, waste, and fraud; inappropriate application without evidence-based literature support (sometimes leading to selective use or non-use of randomized or observational studies for proving biased viewpoints - post priori rather than a priori), and issues related to multiple professional societies having their own agendas to push rather than promulgating the science of interventional pain management.

This perspective is based on a review of articles published in this issue of Pain Physician, information in the public domain, and other relevant articles. Based on the results of this review, various issues of relevance to modern interventional pain management are discussed and the viewpoints of several experts debated.

In conclusion, supporters of interventional pain management disagree on multiple aspects for various reasons while detractors claim that interventional pain management should not exist as a speciality. Issues to be addressed include appropriate use of evidence-based medicine (EBM), overuse, overutilization, and abuse.

Key words: Interventional pain management, interventional techniques, physician payment reform, fraud, abuse, evidence-based medicine, health care costs, comparative effectiveness research, bias

Pain Physician 2010; 13:109-116

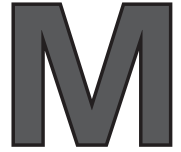

anchikanti et al (1) in this issue describe the confluence of many factors leading to devastating results for interventional pain management. This issue also contains multiple other manuscripts describing the role of urine drug testing, alleged interference to access due to the policies of urine drug testing, medical-legal perspectives of individual opinions, and making sense of the diagnostic accuracy of controlled diagnostic blocks (2-5). 
Manchikanti et al $(6,7)$ described the escalating pace of innovation in health care and interventional pain management with the constant addition of broad and complex areas of interventions. They also described the role of pervasive and persistent unexplained variability in clinical practice and high rates of perceived inappropriate care, combined with increased expenditures, fueling a steadily increasing demand for evidence of clinical effectiveness, to oppose unbalanced growth in interventional pain management (8-11). Consequently, a body of evidence has been demanded regarding safety, effectiveness, appropriate indications, cost-effectiveness, and other attributes of medical care. Failure to understand which services work best under which circumstances, and for which type of patients, contributes to the increasing cost of care, patient safety, and the avoidable loss of life, with any type of practice of medicine. While the United States has the most expensive health care system in the world by a large margin, it has been claimed by many measures of public health that it ranks lower among the western nations (12). Manchikanti et al (1) describe the impact on interventional pain management based on payment systems (physician office, ambulatory surgical center, and hospital outpatient department payments); overuse, abuse, waste, and fraud; inappropriate application without evidence-based literature; and organizational issues related to multiple societies.

\section{Allegations of Lack of Evidence for Interventional Pain Management}

Interventional pain management has been criticized for lack of evidence demonstrating an increasing prevalence of chronic pain in general and, in particular the lack of effectiveness of interventional techniques. As detailed by Manchikanti et al $(1,13)$, there is substantial evidence with regards to escalating disabilities and the economic impact of chronic pain. In fact, a recent study by Freburger et al (14) showed an annual increase of $11.6 \%$ in the overall prevalence of low back pain across all demographic groups. In addition, the controversial issues of duration and chronicity of pain have been resolved based on extensive literature illustrating that chronic pain lasts for months to years with tendencies to recur and relapse $(1,13)$. Even then, the literature concerning interventional pain management continues to be controversial with claims of ineffectiveness and inappropriate care $(1,6,7,15-32)$. However, advances in the understanding of the structural basis of chronic spinal pain, the principles of evidence-based medicine (EBM), and comparative effectiveness research (CER) may have increased utilization with increased access $(6,7,33-78)$. Manchikanti et al $(1,6,7)$ have shown the inappropriate utilization of EBM principles and their application to deny evidence for interventional techniques. At times, "the lack of evidence" has been incorrectly interpreted as "evidence for the lack of effectiveness."

Bogduk and Fraifeld (19) despite their contribution and claim to guardianship of research in interventional pain techniques, fall short and join others (20-32) who continue to attempt to derail interventional pain management. Their view may be influenced by individual as well as specific group bias, academic advancement, lack of understanding of procedural aspects with undue focus on methodology, and societal and individual politics. Surprisingly, many authors continue to exclude selectively some of the well designed studies and therefore provide a biased and incomplete evaluation of evidence. This in part is due to a lack of understanding the differences among multiple randomized trials with consideration of local anesthetic effect in a closed space or over a nerve as placebo. Finally, some opinions are based on pure financial impact (29-32). In a recent editorial, Bogduk and Fraifeld (19) described that interventional pain management faces a crisis - the same concern shared by Manchikanti et al (1) and numerous interventional pain management physicians. This shared concern becomes significantly divided when reviewing the evidence which is already present and the methodology of evidence creation. Basically, Bogduk and Fraifeld (19) claim that there is no solid evidence (randomized controlled trials) in support of interventional techniques and it is an expensive proposition to produce any such evidence. They present sample costs of randomized trials and detail multiple challenges and hurdles facing the generation of good evidence which will be acceptable to policy makers and insurers. They propose a reversal of the long-standing value and credibility of randomized controlled trials which are considered as the gold standard. Instead they recommend implementation of (less costly and less complicated) observational evidence. Therefore, they not only fall short of recognizing the existence of randomized controlled trials and observational evidence, but also retreat to a less credible methodology of evidence generation. One might question the soundness of this proposal amid their admittance of challenges facing the acceptance of current randomized controlled trials that are not replicated or performed in a specific group of patients. Obviously, selective inclusion and exclusion of evidence, 
especially when combined with biases for or against a specific organization, entity, individual, or technique will lead to erroneous and biased conclusions.

In the same issue of Pain Medicine Journal as Bogduk and Fraifeld's article, Richeimer (20) makes his "case against the Interventional Pain Medicine label" under the section of "Perspective," which is based on "having practiced as psychiatrist, anesthesiologist, and pain medicine specialist." The author takes out his frustrations on the creation of interventional pain management as a subspecialty and even "the new subspecialty society of American Society of Interventional Pain Physicians." He wrongfully implies that interventional pain physicians are viewed as technicians and not as "doctors for diagnosis, consultation, and comprehensive treatment planning" and advises we should not become like interventional radiologists who are "simply filling orders of other physicians!" At the same time, one has to agree with the authors' recommendation on teaching interventional procedures along with comprehensive evaluation and management to those seeking fellowship training in pain medicine. This view is shared by the American Society of Interventional Pain Physicians (ASIPP) and is reflected in its review course teachings, publications, and diversity of its membership.

The authors also advocates prescribing pain medications (opioids) to avoid big jury awards for untreated pain and suffering and he implies if pain doctors do not prescribe them, they "should stop calling themselves pain specialists." This view seems less biased than one expressed recently by a senior editor of the same journal advocating opioid prescription: "at some point, we must say if you are going to be a doctor, you must treat pain" (79). Despite extensive abuse, the appropriate use of opioids based on peer-reviewed guidelines has been recommended by interventional pain physicians, and focused review courses on opioids followed by a certification exam have been long implemented by the American Board of Interventional Pain Physicians (ABIPP) (80-92). The National Survey on Drug Use and Health (NSDUH) reported that in 2007, an estimated 5.2 million $(2.1 \%$ of the population age 12 and older) used prescription pain medications for nonmedical purposes in the last month (93). According to statistics released by the US Centers for Disease Control and Prevention's (CDC) National Center for Health Statistics (NCHS), the number of fatal poisonings involving opioid drugs more than tripled between 1999 and 2006 (94). The role of opioid diversion in such deaths has been established in certain geographic areas. Between 1999 and 2004, in West Virginia, more than
$93 \%$ of deaths caused by unintentional medication overdose were related to opioid analgesics (90). The United States constitutes only $4.6 \%$ of the world's population, consumes $80 \%$ of the global opioid supply, and $99 \%$ of the global hydrocodone supply, as well as two-thirds of the world's illegal drugs (81). The serious safety issues surrounding opioid prescription has prompted some to recommend careful screening and close monitoring of patients by their physicians in order to prevent diversion (91), which in itself may escalate health care costs and illustrates one avenue for overuse, abuse, and fraud. Kuehn (79), in a recent perspective in JAMA, notes that the proposal for safe opioid prescription has met resistance from health care worker organizations and other groups, which argue that mandatory physician training would ultimately limit patient access to pain medication. Thus, it seems different standards apply to pain medicine versus interventional pain management, with the issue of increasing deaths linked to opioid medication not being addressed as either a health issue or an economic one (cost of lives lost). Thus, it is essential to balance the need for opioid treatment with serious safety issues, personal biases and advocacy opinions set aside. This balanced approach needs to be based on establishing medical necessity through careful evaluation of each patient.

In the age of CER, depicted as the natural progression of EBM, the authors claims credibility for most of his "perspective" based on 8 years of experience as chief of pain medicine in an academic setting, even though interventional pain management has been recognized for a longer period of time. He does not hesitate to adhere to anecdotal evidence and openly claims that "money appears to be a key issue" with regards to interventional pain medicine (20). Richeimer (20) also questions the need for independent interventional pain organizations and proposes those societies "would best be part of one of the existing pain organizations such as the American Pain Society or the American Academy of Pain Medicine." By doing so, the author ignores the existence of the International Spine Intervention Society (ISIS), which transformed from the International Spinal Injection Society. In fact, he also ignores the existence of ASIPP, which is larger than any other pain society. Many of its members belong to multiple societies.

\section{INAPPROPRIATE UTILIZATION}

Inappropriate utilization of interventional techniques has been a topic of discussion in recent years 
$(6,7,9-11)$.

Substantial growth has been attributed to the explosive growth of physicians performing these procedures without training, lack of enforcement of local coverage determinations (LCDs), lack of LCDs, and finally economic incentives. However, these issues will not be resolved based on the exclusion of the literature and the inappropriate methodologies applied with personal biases. While the American Pain Society (APS) guidelines show that they are prepared as APS-AAPM (American Academy of Pain Medicine) guidelines, AAPM claims no role in preparation of these guidelines.

Gilbert et al $(2,3)$ painstakingly show alleged interference to the access of care for patients without urine drug testing. Based on Gilbert et al $(2,3)$, if a patient receives 3.4 tests per year it is expected, based on these manuscripts, without interference from regulators, that in-office urine drug testing and laboratory confirmation will cost approximately $\$ 450$ minimum per test and per patient a minimum $\$ 1,530$ per year. In contrast, the cost for an average number of epidural injections for a patient over a period of one year is less when it is performed in an office or ambulatory surgery center (ASC) setting, as if it is performed in a hospital outpatient department, which can be slightly more expensive. Further, as described in the manuscripts, if these drug tests are performed during each visit the cost can easily exceed $\$ 6,000$ per year equivalent to a single person's health care premium in the United States. Such behaviors bring up the issue of exploding health care costs in the United States.

One of the other reasons mentioned quite frequently is medical liability costs. Medical liability costs are predominantly blamed on attorneys; however, the responsibility for costs rests upon not only the trial attorneys, but also physicians who practice poor medicine and finally physicians who knowingly or unknowingly, with or without bias and with or without financial interests may be contributing by their so-called my-wayor-the-highway philosophy. Helm et al (4) show the consequences of such behaviors. The issue of expert testimony by the board members against other members was brought to the attention of the board of directors at the ISIS annual meeting (95). The call made for creation of an ethics committee was rejected by the board of directors, in part because "ISIS does not have the resources to fully fund and maintain a separate ethics committee or section." Consequently, the president of ISIS was assigned by the executive committee to investigate the matters personally and provide a report to the membership. The data gathered provided "no prima facie evidence of bias or excesses" and concluded that providing expert testimony "does not constitute any breach of ethics."

Much has been written about the value and validity of diagnostic blocks with one spectrum stating many types of pain, including discogenic, facet joint, and sacroiliac joint pain, may not even exist and others stating that it is highly prevalent and no diagnostic blocks or single diagnostic blocks with $50 \%$ pain relief are appropriate as a controlled diagnostic block. In general, precision diagnostic blocks are used to clarify multiple challenging situations, such as determining the pathophysiology of clinical pain, the site of nociception, and the pathway of afferent and neural signals. Diagnostic facet joint nerve blocks have been shown to have significant evidence classified as moderate to strong in the diagnosis of low back pain without radiculitis or disc herniation, utilizing multiple studies with strict criteria of $80 \%$ pain relief with ability to perform previously painful movements with controlled diagnostic blocks $(5,18,45,63,64,66)$. These studies showed the prevalence of lumbar facet joint pain in $21 \%$ to $40 \%$ in the heterogenous population with chronic low back pain, $34 \%$ to $48 \%$ in thoracic pain, $36 \%$ to $67 \%$ in neck pain, with false-positive rates of $17 \%$ to $49 \%$ in the lumbar spine, $42 \%$ to $58 \%$ in the thoracic spine, and $27 \%$ to $63 \%$ in the cervical spine. At the end of one year, the diagnosis was confirmed in $75 \%$ of the group with $50 \%$ relief (5), whereas it was $93 \%$ in the group with $80 \%$ relief. At the end of the 2-year follow-up, the diagnosis of lumbar facet joint pain was sustained in $51 \%$ of the patients in the group with $50 \%$ relief, whereas it was sustained in $89.5 \%$ of the patients with $80 \%$ relief (5). The results differed between $50 \%$ relief and $80 \%$ relief with a prevalence of $61 \%$ facet joint pain with dual blocks with $50 \%$ relief, and $31 \%$ with dual blocks with $80 \%$ relief; whereas with only a single block, the prevalence was $73 \%$ with $50 \%$ relief and $53 \%$ in the $80 \%$ relief group (5).

Further, Manchikanti et al (5) clearly demonstrate that it is not prudent to utilize mediocre standards and continue to perform treatments which will be ineffective. Other studies also have shown the reliability of these interventions with multiple variables (96-102). Manchikanti et al (5) illustrated the implications of $50 \%$ relief, $80 \%$ relief, single block, or controlled diagnostic blocks. They concluded that controlled diagnostic lumbar facet joint nerve blocks are valid utilizing the criteria of $80 \%$ pain relief and the ability to 
perform previously painful movements, with sustained diagnosis of lumbar facet joint pain in at least $89.5 \%$ of the patients at the end of 2-year follow-up. In contrast, the diagnosis was sustained in $51 \%$ of the patients with $50 \%$ relief at the end of 2 years and the prevalence was $61 \%$ with dual $50 \%$ blocks and $31 \%$ in patients with $80 \%$ or greater pain relief. Utilizing similar protocols, a single block and $\geq 50 \%$ relief, the prevalence will be $73 \%$ and $53 \%$ in $\geq 80 \%$ relief. Thus, using a criteria of $\geq 80 \%$ relief and use of a double diagnostic paradigm leads to a "precision" diagnostic decrease in prevalence from $73 \%$ to $53 \%$ with one block and a decrease to $31 \%$ in double diagnostic blocks. It is our firm belief that employing such strict criteria in double diagnostic blocks and utilizing the $\geq 80 \%$ pain relief criteria as a cutoff will lead to improved diagnostic accuracy and less misutilization of the healthcare system as related to facet interventions.

Recently, Cohen et al (103) compared $0.25 \mathrm{~mL}$ versus $0.5 \mathrm{~mL}$ in the diagnostic cervical facet joint nerve blocks. Yet, in another controversy, the results of pa- tients receiving $0.25 \mathrm{~mL}$ showed $54.5 \%$ of patients demonstrated pain relief, whereas specificity was better with $0.25 \mathrm{~mL}$. In contrast, patients receiving higher volumes $(0.5 \mathrm{~mL})$ showed reduction in prevalence by $50 \%$ ( $25 \%$ versus $54.5 \%$ ) based on pain relief. Therefore, based on the work of Cohen et al (103) $0.25 \mathrm{~mL}$ may lead to unnecessary radiofrequency neurotomies or other therapeutic interventions.

In summary, while supporters of interventional pain management continue to disagree on multiple aspects of their practice for various reasons, detractors are claiming victory. As a young medical specialty, interventional pain management needs to address numerous vital issues including EBM, CER, overuse, over utilization, and abuse leading to increases in cost and reimbursement, which in turn may result in serious consequences threatening our very future. In the process, we need to adhere to our principles and partner with our informed patients to reduce pain and suffering while improving function and quality of life, using the best available evidence in the most cost effective way.

\section{References}

1. Manchikanti L, Singh V, Boswell MV. Interventional pain management at crossroads: The perfect storm brewing for a new decade of challenges. Pain Physician 2010; E111-E140.

2. Gilbert JW, Wheeler GR, Mick GE, Storey BB, Herder SL, Richardson GB, Watts E, Gyarteng-Dakwa K, Marino BS, Kenney CM, Siddiqi M, Broughton PG. Urine drug testing in the treatment of chronic non-cancer pain in a Kentucky private neuroscience practice: The potential effect of medicare benefit changes in Kentucky. Pain Physician 2010; 187194.

3. Gilbert JW, Wheeler GR, Mick GE, Storey $\mathrm{BB}$, Herder $\mathrm{SL}$, Richardson $\mathrm{GB}$, Watts E, Gyarteng-Dakwa K, Marino BS, Kenney CM, Siddiqi M, Broughton PG. Importance of urine drug testing in the treatment of chronic non-cancer pain: Implications of recent Medicare policy changes in Kentucky. Pain Physician 2010; 167-186.

4. Helm S, Glaser S, Falco FJE, Henry B. A medical-legal review regarding the standard of care for epidural injections, with particular reference to a closed case. Pain Physician 2010;145-150.

5. Manchikanti L, Pampati S, Cash KA. Making sense of accuracy of diagnostic lumbar facet joint nerve blocks: An assessment of implications of $50 \%$ relief, $80 \%$ relief, single block, or controlled diagnostic blocks. Pain Physician 2010; 133-143.

6. Manchikanti L, Falco FJE, Boswell MV, Hirsch JA. Facts, fallacies, and politics of comparative effectiveness research: Part 1. Basic considerations. Pain Physician 2010; 13:E23-E54.

7. Manchikanti L, Falco FJE, Boswell MV, Hirsch JA. Facts, fallacies, and politics of comparative effectiveness research: Part 2. Implications for interventional pain management. Pain Physician 2010; 13:E55-E79.

8. Manchikanti L, Hirsch JA. Obama health care for all Americans: Practical implications. Pain Physician 2009; 12:289304.

9. Manchikanti L. Health care reform in the United States: Radical surgery needed now more than ever. Pain Physician 2008; 11:13-42.

10. Manchikanti L, Singh V, Pampati V, Smith HS, Hirsch JA. Analysis of growth of interventional techniques in manag. ing chronic pain in the medicare population: A 10-year evaluation from 1997 to 2006. Pain Physician 2009; 12:9-34.

11. US Department of Health and Human
Services. Office of Inspector General (OIG). Medicare Payments for Facet Joint Injection Services (OEl-05-0700200). September 2008. www.oig.hhs. gov/oei/reports/oei-05-07-00200.pdf

12. Eden J, Wheatley B, McNeil B, Sox H. Knowing What Works in Health Care: $A$ Roadmap for the Nation. National Academies Press, Washington, DC, 2008.

13. Manchikanti L. Singh V, Datta S, Cohen SP, Hirsch JA. Comprehensive review of epidemiology, scope, and impact of spinal pain. Pain Physician 2009; 12:E35E70.

14. Freburger JK, Holmes GM, Agans RP, Jackman AM, Darter JD, Wallace AS, Castel LD, Kalsbeek WD, Carey TS. The rising prevalence of chronic low back pain. Arch Intern Med 2009; 169:251258.

15. Chou R, Atlas SJ, Stanos SP, Rosenquist RW. Nonsurgical interventional therapies for low back pain: A review of the evidence for an American Pain Society clinical practice guideline. Spine (Phila Pa 1976) 2009; 34:1078-1093.

16. Staal JB, de Bie RA, de Vet HC, Hildebrandt J, Nelemans P. Injection therapy for subacute and chronic low back pain: An updated Cochrane review. Spine (Phila Pa 1976) 2009; 34:49-59. 
17. Armon C, Argoff CE, Samuels J, Backonja M. Assessment: Use of epidural steroid injections to treat radicular lumbosacral pain: Report of the Therapeu tics and Technology Assessment Subcommittee of the American Academy of Neurology. Neurology 2007; 68:723729.

18. Manchikanti L, Boswell MV, Singh V, Benyamin RM, Fellows B, Abdi S, Buenaventura RM, Conn A, Datta S, Derby R, Falco FJE, Erhart S, Diwan S, Hayek SM, Helm S, Parr AT, Schultz DM, Smith HS, Wolfer LR, Hirsch JA. Comprehensive evidence-based guidelines for interventional techniques in the management of chronic spinal pain. Pain Physician 2009: 12:699-802.

19. Bogduk N, Fraifeld EM. Proof or consequences: Who shall pay for the evidence in pain medicine? Pain Medicine 2010; 11:1-2.

20. Richeimer SH. Are we lemmings going off a cliff? The case against the "Interventional" pain medicine label. Pain Medicine 2010; 11:3-5.

21. Chou R, Huffman L. Evaluation and Management of Low Back Pain: Evidence Review. American Pain Society, Glenview, IL, 2009. www.ampainsoc. org/pub/pdf/LBPEvidRev.pdf

22. Chou R, Fanciullo GJ, Fine PG, Adler JA, Ballantyne JC, Davies P, Donovan MI, Fishbain DA, Foley KM, Fudin J, Gilson AM, Kelter A, Mauskop A, O’Connor PG, Passik SD, Pasternak GW, Portenoy RK, Rich BA, Roberts RG, Todd KH, Miaskowski C; American Pain Society-American Academy of Pain Medicine Opioids Guidelines Panel. Clinical guidelines for the use of chronic opioid therapy in chronic noncancer pain. J Pain 2009; 10:113-130.

23. Chou R. 2009 Clinical guidelines from the American Pain Society and the American Academy of Pain Medicine on the use of chronic opioid therapy in chronic noncancer pain: What are the key messages for clinical practice? Pol Arch Med Wewn 2009; 119:469-477.

24. Chou R, Baisden J, Carragee EJ, Resnick DK, Shaffer WO, Loeser JD. Surgery for low back pain: A review of the evidence for an American Pain Society Clinical Practice Guideline. Spine (Phila Pa 1976) 2009; 34:1094-1109.

25. Levin JH. Prospective, double-blind, randomized placebo-controlled trials in interventional spine: What the highest quality literature tells us. Spine J
2009; 9:690-703.

26. Manchikanti L, Shah RV, Datta S, Singh V. Critical evaluation of interventional pain management literature provides inaccurate conclusions. Spine / 2009; 9:706-708.

27. Smuck M, Levin JH. RE: Manchikanti L, Singh V, Falco FJE, Cash KA, Fellows B. Cervical medial branch blocks for chronic cervical facet joint pain: A randomized double-blind, controlled trial with one-year follow-up. Spine 2008; 33:1813-20. Spine (Phila PA 1976) 2009; 34:1116-1117.

28. O’Neill C. Re: Manchikanti L, Singh V, Falco FJE, et al. Cervical medial branch blocks for chronic cervical facet joint pain. A randomized, double-blind, controlled trial with one-year follow-up. Spine 2008; 33:1813-20. Spine (Phila Pa 1976) 2009; 34:1117-1118.

29. American College of Occupational and Environmental Medicine (ACOEM). Low back Disorders. In: Occupational Medicine Practice Guidelines: Evaluation and Management of Common Health Problems and Functional Recovery of Workers, Second Edition. American College of Occupational and Environmental Medicine Press, Elk Grove Village, 2007.

30. American College of Occupational and Environmental Medicine (ACOEM). Chronic Pain. In: Occupational Medicine Practice Guidelines: Evaluation and Management of Common Health Problems and Functional Recovery of Workers, Second Edition. American College of Occupational and Environmental Medicine Press, Elk Grove Village, 2008.

31. Dennison PL, Kennedy CW. Official Dis ability Guideline, 15th ed. Work Loss Data Institute, 2010.

32. HAYES, Inc. Independent Health Technology Assessment Company. www. hayesinc.com

33. Manchikanti L, Singh V, Cash KA, Pampati V, Damron KS, Boswell MV. Preliminary results of randomized, equivalence trial of fluoroscopic caudal epidural injections in managing chronic low back pain: Part 2. Disc herniation and radiculitis. Pain Physician 2008; 11:801-815.

34. Manchikanti L, Singh V, Cash KA, Pampati V, Datta S. Preliminary results of randomized, equivalence trial of fluoroscopic caudal epidural injections in managing chronic low back pain: Part 3. Post surgery syndrome. Pain Physician
2008; 11:817-831.

35. Manchikanti L, Cash KA, McManus CD, Pampati V, Abdi S. Preliminary results of randomized, equivalence trial of fluoroscopic caudal epidural injections in managing chronic low back pain: Part 4. Spinal stenosis. Pain Physician 2008; 11:833-848.

36. Manchikanti L, Singh V, Falco FJE, Cash KA, Pampati V. Effectiveness of thoracic medial branch blocks in managing chronic pain: A preliminary report of a randomized, double-blind controlled trial; Clinical trial NCTo0355706. Pain Physician 2008; 11:491-504.

37. Manchikanti L, Singh V, Falco FJ, Cash KA, Fellows B. Cervical medial branch blocks for chronic cervical facet joint pain: A randomized double-blind, controlled trial with one-year follow-up. Spine (Phila Pa 1976) 2008; 33:18131820.

38. Manchikanti L, Singh V, Falco FJ, Cash KA, Pampati V. Lumbar facet joint nerve blocks in managing chronic facet joint pain: One-year follow-up of a randomized, double-blind controlled trial; Clinical Trial NCTo0355914. Pain Physician 2008; 11:121-132.

39. Helm S, Hayek S, Benyamin R, Manchikanti L. Systematic review of the effectiveness of thermal annular procedures in treating discogenic low back pain. Pain Physician 2009; 12:207-232.

40. Conn A, Buenaventura R, Datta S, Abdi S, Diwan S. Systematic review of caudal epidural injections in the management of chronic low back pain. Pain Physician 2009; 12:109-135.

41. Parr AT, Diwan S, Abdi S. Lumbar interlaminar epidural injections in managing chronic low back and lower extremity pain: A systematic review. Pain Physician 2009; 12:163-188.

42. Benyamin RM, Singh V, Parr AT, Conn A, Diwan S, Abdi S. Systematic review of the effectiveness of cervical epidurals in the management of chronic neck pain. Pain Physician 2009; 12:137-157.

43. Buenaventura RM, Datta S, Abdi S, Smith HS. Systematic review of therapeutic lumbar transforaminal epidural steroid injection. Pain Physician 2009; 12:233-251.

44. Singh V, Manchikanti L, Shah RV, Dunbar EE, Glaser SE. Systematic review of thoracic discography as a diagnostic test for chronic spinal pain. Pain Physician 2008; 11:631-642. 
45. Atluri S, Datta S, Falco FJ, Lee M. Systematic review of diagnostic utility and therapeutic effectiveness of thoracic facet joint interventions. Pain Physician 2008; 11:611-629.

46. Manchikanti L, Cash KA, McManus CD, Pampati V, Singh V, Benyamin RM. The preliminary results of a comparative effectiveness evaluation of adhesiolysis and caudal epidural injections in managing chronic low back pain secondary to spinal stenosis: A randomized, equivalence controlled trial. Pain Physician 2009; 12:E341-E354.

47. Manchikanti L, Singh V, Cash KA, Pampati V, Datta S. A comparative effectiveness evaluation of percutaneous adhesiolysis and epidural steroid injections in managing lumbar post surgery syndrome: $A$ randomized, equivalence controlled trial. Pain Physician 2009; 12:E355-E368.

48. Manchikanti L, Dunbar EE, Wargo BW, Shah RV, Derby R, Cohen SP. Systematic review of cervical discography as a diagnostic test for chronic spinal pain. Pain Physician 2009; 12:305-321.

49. Smith HS, Chopra P, Patel VB, Frey ME, Rastogi R. Systematic review on the role of sedation in diagnostic spinal interventional techniques. Pain Physician 2009; 12:195-206.

50. Epter RS, Helm S, Hayek SM, Benyamin RM, Smith HS, Abdi S. Systematic review of percutaneous adhesiolysis and management of chronic low back pain in post lumbar surgery syndrome. Pain Physician 2009; 12:361-378.

51. Patel VB, Manchikanti L, Singh V, Schultz DM, Hayek SM, Smith HS. Systematic review of intrathecal infusion systems for long-term management of chronic non-cancer pain. Pain Physician 2009; 12:345-360.

52. Hayek SM, Helm S, Benyamin RM, Singh V, Bryce DA, Smith HS. Effectiveness of spinal endoscopic adhesiolysis in post lumbar surgery syndrome: A systematic review. Pain Physician 2009; 12:419-435.

53. Hirsch JA, Singh V, Falco FJE, Benyamin RM, Manchikanti L. Automated percutaneous lumbar discectomy for the contained herniated lumbar disc: A systematic assessment of evidence. Pain Physician 2009; 12:601-620.

54. Frey ME, Manchikanti L, Benyamin RM, Schultz DM, Smith HS, Cohen SP. Spinal cord stimulation for patients with failed back surgery syndrome: A sys- tematic review. Pain Physician 2009; 12:379-397.

55. Singh V, Manchikanti L, Benyamin RM, Helm S, Hirsch JA. Percutaneous lumbar laser disc decompression: A systematic review of current evidence. Pain Physician 2009; 12:573-588.

56. Singh V, Benyamin RM, Datta S, Falco FJE, Helm S, Manchikanti L. Systematic review of percutaneous lumbar mechanical disc decompression utilizing Dekompressor. Pain Physician 2009; 12:589-599.

57. Manchikanti L, Derby R, Benyamin RM, Helm S, Hirsch JA. A systematic review of mechanical lumbar disc decompression with nucleoplasty. Pain Physician 2009; 12:561-572.

58. Rupert MP, Lee M, Manchikanti L, Datta S, Cohen SP. Evaluation of sacroiliac joint interventions: A systematic appraisal of the literature. Pain Physician 2009; 12:399-418.

59. Manchikanti L, Glaser S, Wolfer L, Derby $\mathrm{R}$, Cohen SP. Systematic review of lumbar discography as a diagnostic test for chronic low back pain. Pain Physician 2009; 12:541-559.

6o. Manchikanti L, Singh V, Derby R, Schultz DM, Benyamin RM, Prager JP, Hirsch JA. Reassessment of evidence synthesis of occupational medicine practice guidelines for interventional pain management. Pain Physician 2008; 11:393482.

61. Manchikanti L, Singh V, Derby R, Helm $S$, Trescot AM, Staats PS, Prager JP, Hirsch JA. Review of occupational medicine practice guidelines for interventional pain management and potential implications. Pain Physician 2008; 11:271-289.

62. Manchikanti L, Singh V, Helm S, Trescot AM, Hirsch JA. A critical appraisal of 2007 American College of Occupational and Environmental Medicine (ACOEM) practice guidelines for interventional pain management: An independent review utilizing AGREE, AMA, IOM, and other criteria. Pain Physician 2008; 11:291-310.

63. Falco FJE, Erhart S, Wargo BW, Bryce DA, Atluri S, Datta S, Hayek SM. Systematic review of diagnostic utility and therapeutic effectiveness of cervical facet joint interventions. Pain Physician 2009; 12:323-344.

64. Datta S, Lee M, Falco FJE, Bryce DA, Hayek SM. Systematic assessment of diagnostic accuracy and therapeutic utility of lumbar facet joint interventions. Pain Physician 2009; 12:437460.

65. Manchikanti L, Singh V, Helm S, Schultz DM, Datta S, Hirsch J. An introduction to an evidence-based approach to interventional techniques in the management of chronic spinal pain. Pain Physician 2009; 12:E1-E33.

66. Manchikanti L, Boswell MV, Singh V, Derby R, Fellows B, Falco FJE, Datta S, Smith HS, Hirsch JA. Comprehensive review of neurophysiologic basis and diagnostic interventions in manag. ing chronic spinal pain. Pain Physician 2009; 12:E71-E120.

67. Manchikanti L, Boswell MV, Datta S, Fellows B, Abdi S, Singh V, Benyamin RM, Falco FJE, Helm S, Hayek S, Smith HS. Comprehensive review of therapeutic interventions in managing chronic spinal pain. Pain Physician 2009; 12:E123E198.

68. Manchikanti L, Singh V, Pampati V, Boswell MV, Benyamin RM, Hirsch JA. Description of documentation in the management of chronic spinal pain. Pain Physician 2009: 12:E199-E224.

69. Manchikanti L, Helm S, Singh V, Benyamin RM, Datta S, Hayek S, Fellows B, Boswell MV. An algorithmic approach for clinical management of chronic spinal pain. Pain Physician 2009; 12:E225E264.

70. Manchikanti L. Evidence-based medicine, systematic reviews, and guidelines in interventional pain management: Part 1: Introduction and general considerations. Pain Physician 2008; 11:161-186.

71. Manchikanti L. Evidence-based medicine, systematic reviews, and guidelines in interventional pain management: Part 2: Randomized controlled trials. Pain Physician 2008; 11:717773 .

72. Manchikanti L, Smith HS, Hirsch JA. Evidence-based medicine, systematic reviews, and guidelines in interventional pain management: Part 3: Systematic reviews and meta-analyses of randomized trials. Pain Physician 2009; 12:3572.

73. Manchikanti L, Singh V, Smith HS, Hirsch JA. Evidence-based medicine, systematic reviews, and guidelines in interventional pain management: Part 4: Observational studies. Pain Physician 2009; 12:73-108.

74. Manchikanti L, Derby R, Wolfer LR, 
Singh V, Datta S, Hirsch JA. Evidencebased medicine, systematic reviews, and guidelines in interventional pain management: Part 5: Diagnostic accuracy studies. Pain Physician 2009; 12:517-540.

75. Manchikanti L, Datta S, Smith HS, Hirsch JA. Evidence-based medicine, systematic reviews, and guidelines in interventional pain management: Part 6: Systematic reviews and meta-analyses of observational studies. Pain Physician 2009; 12:819-850.

76. Manchikanti L, Derby R, Wolfer LR, Singh V, Datta S, Hirsch JA. Evidencebased medicine, systematic reviews, and guidelines in interventional pain management: Part 7: Systematic reviews and meta-analyses of diagnostic accuracy studies. Pain Physician 2009; 12:929-963.

77. Wolfer L, Derby R, Lee JE, Lee SH. Systematic review of lumbar provocation discography in asymptomatic subjects with a meta-analysis of false-positive rates. Pain Physician 2008; 11:513538.

78. Manchikanti L, Cash KA, McManus CD, Pampati V, Smith HS. Preliminary results of randomized, equivalence trial of fluoroscopic caudal epidural injections in managing chronic low back pain: Part 1. Discogenic pain without disc herniation or radiculitis. Pain Physician 2008; 11:785-800.

79. Kuehn B. Safety plan for opioids meets resistance. Opioid-linked deaths continue to soar. JAMA 2010; 303:495497.

80. Trescot AM, Helm S, Hansen H, Benyamin R, Glaser SE, Adlaka R, Patel S, Manchikanti L. Opioids in the management of chronic non-cancer pain: An update of American Society of the Interventional Pain Physicians' (ASIPP) guidelines. Pain Physician 2008; 11:S5S62.

81. Manchikanti L, Singh A. Therapeutic opioids: A ten year perspective on the complexities and complications of the escalating use, abuse, and non-medical use of opioids and other psychotherapeutics. Pain Physician 2008; 11: S63-S88.

82. Smith HS, Deer TR, Staats PS, Singh V, Sehgal N, Cordner H. Intrathecal drug delivery. Pain Physician 2008; 11:S89S104.

83. Benyamin R, Trescot AM, Datta S, Bue- naventura R, Adlaka R, Sehgal N, Glaser SE, Vallejo R. Opioid complications and side effects. Pain Physician 2008; 11:S105-S120.

84. Smith H. Peripherally-acting opioids. Pain Physician 2008; 11:S121-S132.

85. Trescot AM, Datta S, Lee M, Hansen H. Opioid pharmacology. Pain Physician 2008; 11:S133-S154.

86. Manchikanti L, Atluri S, Trescot AM, Giordano J. Monitoring opioid adherence in chronic pain patients: Tools, techniques, and utility. Pain Physician 2008; 11:S155-S180.

87. Trescot AM, Datta S, Glaser S, Sehgal $\mathrm{N}$, Hansen H, Benyamin R, Patel S. Effectiveness of opioids in the treatment of chronic non-cancer pain. Pain Physician 2008; 11:S181-S200.

88. Silverman S. Opioid induced hyperalgesia: Clinical implications for the pain practitioner. Pain Physician 2009; 12:679-684.

89. Manchikanti KN, Manchikanti L, Damron KS, Pampati V, Fellows B. Increasing deaths from opioid analgesics in the United States: An evaluation in an interventional pain management practice. J Opioid Manage 2008; 4:271283.

90. Hall AJ, Logan JE, Toblin RL, Kaplan JA, Kraner JC, Bixler D, Crosby AE, Paulozzi LJ. Patterns of abuse among unintentional pharmaceutical overdose fatalities. JAMA 2008; 300:2613-2620.

91. McLellan AT, Turner B. Prescription opioids, overdose deaths, and physician responsibility. JAMA 2008; 300:26132620.

92. Manchikanti L, Malla Y, Wargo BW, Cash KA, Pampati V, Damron KS, McManus $C D$, Brandon DE. Protocol for accuracy of point of care (POC) or in-office urine drug testing (immunoassay) in chronic pain patients: A prospective analysis of immunoassay and liquid chromatog. raphy tandem mass spectometry (LC/ MS/MS). Pain Physician 2010; 13:E1E22.

93. Substance Abuse and Mental Health Services Administration, Office of Applied Studies. (February 5, 2009). The NSDUH Report: Trends in Nonmedical Use of Prescription Pain Relievers: 2002 to 2007. Rockville, MD. oas. samhsa.gov $/ 2 \mathrm{~kg} /$ painrelievers/nonmedicaltrends.cfm

94. Warner M, Chen LH, Makuc DM. Increase in fatal poisonings involving opioid analgesics in the United States, 1999-2006. NCHS Data Brief, No. 22, Hyattsville, MD, National Center for Health Statistics, September 2009. www.cdc.gov/nchs/data/databriefs/ db22.pdf

95. Letter to International Spine Intervention Society (ISIS) from Way Yin, MD, President RE: President's report to ISIS Board of Directors: Board of Directors and Medical Malpractice Testimony. February 2, 2010.

96. Pampati S, Cash KA, Manchikanti L. Accuracy of diagnostic lumbar facet joint nerve blocks: A 2-year follow-up of 152 patients diagnosed with controlled diagnostic blocks. Pain Physician 2009; 12:855-866.

97. Manchikanti L, Singh V, Pampati V. Are diagnostic lumbar medial branch blocks valid? Results of 2-year follow up. Pain Physician 2003; 6:147-153.

98. Manchikanti L, Cash KA, Pampati V, Fellows B. Influence of psychological variables on the diagnosis of facet joint involvement in chronic spinal pain. Pain Physician 2008; 11:145-160.

99. Manchikanti L, Pampati V, Fellows B, Rivera JJ, Damron KS, Beyer CD, Cash KA. Influence of psychological factors on the ability to diagnose chronic low back pain of facet joint origin. Pain Physician 2001; 4:349-357.

100. Manchikanti L, Manchikanti K, Cash KA, Singh V, Giordano J. Age-related prevalence of facet joint involvement in chronic neck and low back pain. Pain Physician 2008; 11:67-75.

101. Manchikanti L, Manchikanti K, Pampati V, Brandon D, Giordano J. The prevalence of facet joint-related chronic neck pain in postsurgical and non-postsurgical patients: A comparative evaluation. Pain Pract 2008; 8:5-10.

102. Manchikanti L, Manchukonda R, Pampati V, Damron KS, McManus CD. Prevalence of facet joint pain in chronic low back pain in postsurgical patients by controlled comparative local anesthetic blocks. Arch Phys Med Rehabil 2007; 88:449-455.

103. Cohen SP, Strassels SA, Kurihara C, Forsythe A, Buckenmaier CC 3rd, McLean B, Riedy G, Seltzer S. Randomized study assessing the accuracy of cervical facet joint nerve (medial branch) blocks using different injectate volumes. Anesthesiology 2010; 112:144-152. 